\title{
An early infantile epileptic encephalopathy 19 with dyskinesias due to a new GABRA1 gene mutation - identification of the first case in the Polish population
}

\section{Wczesnoniemowlęca encefalopatia padaczkowa 19 z dyskinezami uwarunkowana nową mutacją w genie GABRA1 - pierwszy przypadek w polskiej populacji}

\author{
Agnieszka Oknińska ${ }^{1 *}$, Hanna Mierzewska ${ }^{1 *}$, Robert Śmigiel ${ }^{2}$, Małgorzata Rydzanicz ${ }^{3}$ Anna Walczak² \\ Iwona Terczyńska', Jolanta Tryfon ${ }^{1}$, Rafał Płoski ${ }^{*}$, Elżbieta Szczepanik ${ }^{1^{*}}$ \\ ${ }^{1}$ The Clinic of Children and Adolescent Neurology, The Institute of Mother and Child, Kasprzaka 17A, Warsaw, Poland \\ ${ }^{2}$ Department of Pediatrics and Rare Disorders, Wroclaw Medical University, Bartla 5, Wroclaw, Poland \\ ${ }^{3}$ Department of Medical Genetics, Medical University of Warsaw, Pawinskiego 3c, Warsaw, Poland \\ *equal contribution
}

DOI:10.20966/chn.2017.53.413

\section{ABSTRACT}

Background: Dominant, heterozygous mutations in the GABRA1 gene on chromosome 5 q34 cause a heterogeneous, constantly growing group of neurological disorders. Aim: The aim of the study was to report on an individual with profound psychomotor retardation, extrapyramidal symptoms and epilepsy due to a new mutation in GABRA1 gene (c.799C $>$ A). Material and Methods: The child with unremarkable family and perinatal history, fetal and perinatal primary microcephaly, delayed psychomotor development in a profound degree as well as with impaired global physical development and a failure to thrive. From the first months of life dyskinesias, bruxism, upward eye deviation and oropharyngeal movements were present. However, on sleep EEG generalized spike and wave discharges were present. Whole-exome sequencing (WES) was carried out in the proband. Results: WES results detected disease-causing novel mutation in the GABRA1 gene, the first case in the Polish population. Conclusions: Our observation expands the spectrum of syndromes of EIEE19 associated with GABRA1 gene mutations. This mutation (c.799 C $>$ A) has not been described previously in the literature.

Key words: GABRA1, GABA receptor, EIEE19, infantile epilepsy.

\section{STRESCZEENIE}

Wstęp: Dominujące, heterozygotyczne mutacje w genie GABRA1 zlokalizowanym na chromosomie 5 q34 powodują zróżnicowaną, stale powiększającą się grupę zaburzeń neurologicznych. Cel pracy: Celem pracy jest przedstawienie fenotypu pacjenta z opóźnieniem rozwoju psychoruchowego w stopniu głębokim, objawami pozapiramidowymi oraz padaczką, uwarunkowanych nowo powstałą mutacją w genie GABRA 1 (c.799C >A). Materiał i Metody: Dziecko z nieobciążonym wywiadem rodzinnym, płodowo-okołoporodowym, pierwotnym małogłowiem, opóźnionym rozwojem psychoruchowym w stopniu głębokim jak również z zaburzonym rozwojem fizycznym. Od pierwszych miesięcy życia obserwowano: dyskinezy, bruksizm, zwroty gałek ocznych ku górze, ruchy orofaryngealne. W zapisie EEG we śnie stwierdzono zmiany napadowe uogólnione iglica fala. W celu identyfikacji genów odpowiadających za fenotyp przeprowadzono sekwencjonowanie całego eksomu (WES). Wyniki: Badanie metodą WES wykazało mutację w genie GABRA1, odpowiadającą za chorobę - pierwszy przypadek w polskiej populacji. Wnioski: Opis naszego przypadku poszerza spektrum objawów EIEE19 powiązanych z mutacjami w genie GABRA1. Mutacja (c.799C >A) nie została jak dotychczas opisana w literaturze.

Słowa kluczowe: GABRA1, GABA A receptor, EIEE19, padaczka niemowlęca.

\section{INTRODUCTION}

The term epileptic encephalopathy describes a heterogeneous group of epilepsy syndromes associated with severe cognitive and behavioral disturbances. These disorders vary in their age of onset, etiologies, neurodevelopmental disorders, neuropsychological deficits, seizures types, electroencephalographic (EEG) patterns, developmental outcome and prognosis but all may have a significant impact on neurological development $[1,2]$.
Early infantile epileptic encephalopathy (EIEE) with onset before 1 year of age are characterized by severe seizures (often polymorphic with infantile spasms), frequent interictal epileptiform activity on a disorganized electroencephalogram (EEG) background and developmental regression or retardation [3]. Ohtahara syndrome (OS), West syndrome (WS), early myoclonic encephalopathy (EME), Dravet syndrome (DS), malignant migrating partial seizures of infancy are the best known epileptic encephalopa- 
thies recognized by the International League Against Epilepsy [ILAE Classification 2017, 2014]. However, many infants with these syndromes do not strictly fit within the electroclinical parameters of these syndromes. Recently several new causative genes have been reported in patients both with well-recognized and unclassified EIEE syndromes (currently 58 types have been described in OMIM) $[4,5]$.

EIEE 19 (OMIM \#615744) is an infantile-onset epileptic encephalopathy caused by heterozygous mutations in the GABRA1 gene on chromosome 5q34. The other known mutations of GABA receptors have been linked so far to:

1. Spectrum of idiopathic generalized epilepsies (IGE - old term):

- childhood absence epilepsy (CAE),

- autosomal dominant Juvenile Myoclonic Epilepsy (JME)

- genetic epilepsy with febrile seizures (GEFS+)

2. Dravet Syndrome (DS),

3. West Syndrome (WS),

4. Ohtahara syndrome (OS),

5. Unclassified early infantile epileptic encephalopathy,

6. Febrile Seizures (FS),

7. Autism,

8. Developmental delay.

The aim of this study is to present electroclinical manifestation of epileptic encephalopathy due to a new mutation in the GABRA1 gene and to show the phenotypic variability associated with other mutations in this gene.

\section{THE CASE REPORT \\ Clinical description of Proband}

The girl was the second child of healthy, non-consanguineous Polish parents and was born at term (gestational week 39) after an uneventful pregnancy with a weight of $3365 \mathrm{~g}$ $(0+2 \mathrm{z}$-scores), a length of $59 \mathrm{~cm}$ ( $>3 \mathrm{z}$-scores) and a head circumference of $31 \mathrm{~cm}$ (-2-3 z-scores). The family history was uneventful for genetic disorders, intellectual disability or seizures. Microcephaly and profound psychomotor retardation were observed from neonatal period as well as failure to thrive. There were no dysmorphic features. Physical examination did not show any abnormalities in the internal organs. Neurological examination disclosed: no head control, no eye contact, no social smile, marked axial hypotonia with episodes of extremities hypertonia. From the first months of life oropharyngeal movements, dyskinesias, bruxism, upward eye deviation were present, with no parental reports of evident epileptic seizures. Echocardiography revealed PFO and multi VSD. Diagnostic brain MRI and MRS results were negative. CMV infection was excluded. Hyperamonemias, mitochondrial fatty acid beta oxidation disorders, congenital disorders of glycosylation, aminoacidopathies, organic acidurias, neurotransmitters disorders as well as glucose transporter type 1 deficiency were excluded. Mitochondrial disease was considered unlikely because of normal lactate concentration in serum and cerebrospinal fluid (CSF) and normal MRS results. On sleep - EEG generalized spike and wave discharges were present. Her female karyotype and aCGH were normal. Mutations in the MECP2, CDKL5, ARX, NTNG1, PLP1 genes were excluded.

The patient was last reviewed at the age of 1 year 11 months. Her length was $85 \mathrm{~cm}(0,-2 \mathrm{z}$-scores $)$, her weight was $8.9 \mathrm{~kg}(-2,-3 \mathrm{z}$-scores) and her head circumference was $45 \mathrm{~cm} .(-1-2$ z-scores). According to Brunet - Lezine Scale she was assessed to have profound psychomotor delay without reaching any developmental milestones, however with slightly better eye and social contact. She was unable to stabilize trunk and neck, to turn and vocalize. She presented chaotic, restless movements of her arms and legs; did not smile at people, did not respond to loud sounds. On follow up sleep EEG generalized spike and wave discharges, mostly occipital, were present. The seizures were still not observed by parents. However video footage and the clinical presentation could not have ruled out the unclassified seizures. Epileptic encephalopathy was recognized. The treatment of valproate acid was proposed, but her parents refused it.

\section{METHODS \\ Molecular study}

For further diagnostic processing whole-exome sequencing (WES) with the Nextera kit for EIEE was carried out. Genomic DNA was extracted from blood specimen using standard methods.

\section{RESULTS}

WES results detected disease-causing mutation in the GABRA1 gene (c.799 C>A). Using Sanger sequencing in the proband and parents the mutation was confirmed in the proband and shown to occur de novo.

The mutation c.799 $\mathrm{C}>\mathrm{A}$ which was detected by us is described in ClinVar base (www.ncbi.nlm.nih.gov ) as likely pathogenic variant.

The herein identified de novo variant in GABRAlgen has been submitted to ClinVar and to the LOVD gene variant database at http://www.lovd.nl/GABRA1.

\section{DISCUSSION}

Hereby we present the case of a toddler with profound developmental delay with no progress from neonatal period, primary microcephaly, pyramidal-extrapyramidal tetraparesis and with choreo-athetotic movements. WES results detected disease-causing mutation in the GABRAl gene, which

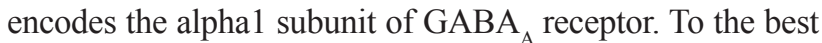
of our knowledge, the patient described above is the first case report who confirms pathogenicity of this mutation.

Gamma-aminobutyric acid (GABA) is the major inhibitory neurotransmitter in the mammalian brain. GABA activates two major types of receptors: $\mathrm{GABA}_{\mathrm{A}}$ and closely related $\mathrm{GABA}_{\mathrm{C}}$, which function as chloride channels and metabotropic $\mathrm{GABA}_{\mathrm{B}}$ receptors [6]. $\mathrm{GABA}_{\mathrm{A}}$ receptors are pentameric channels comprised of different combinations of the following subunits: $\alpha(1-6), \beta(1-3), \gamma(1-3), \gamma$, epsilon, mi. These pentameric complexes consist of 2 alpha and 2 beta subunits, whereas the fifth subunit can belong to any of the other classes [7]. Each subunit consists of a long, variable extracellular region, 4 transmembrane do- 
mains and a variable cytoplasmic region between the third and fourth transmembrane domains. The subunits have been divided into different classes based on amino acid sequence homology, with 70 to $80 \%$ identity within a class, and 30 to $50 \%$ identity between classes $[8,9]$.

To date, mutations associated with epilepsies have been identified in several GABA $\mathrm{A}_{\mathrm{A}}$ receptor subunit - coding genes other than GABRA1: GABRA6 (encoding GABA receptor alpha6 subunit), GABRB2 (beta2 subunit), GABRB3 (beta3 subunit), GABRG2 (gamma2 subunit) and GABRD (delta subunit) [4].

The list of $\mathrm{GABA}_{\mathrm{A}}$ receptor mutations is constantly growing. To date, about 30 presumably pathogenic $G A$ $B R A 1$ variants have been identified in 58 individuals (last review on 15.10 .2017 ) with phenotypes ranging from febrile seizures with normal intellect and development [10, 11] to severe epileptic encephalopathy, such as Dravet Syndrome, Dravet-like Syndrome, Ohtahara and West Syndrome with difficulty to treat seizures $[4,11,12]$.

It has been shown that mutations in $\mathrm{GABA}_{\mathrm{A}}$ receptor alpha1 subunit also play a significant role in contributing to the $\mathrm{GEFS}^{+}$phenotype. The phenotypes in families with $\mathrm{GEFS}^{+}$include typical febrile seizures (FS) seen in early childhood as well as febrile seizures plus $\left(\mathrm{FS}^{+}\right)$in which either attacks with fever extend beyond age 6 years or afebrile generalized tonic-clonic seizures (GTCS).

However, no clear genotype-phenotype correlation has emerged from these cases, so genotype has not been able to explain the clinical heterogenicity. What is interesting, the same mutations cause different phenotype spectrum. For example, the mutation p.R112Q is identified in two patients with classic phenotype of Dravet syndrome but also in one patient with seizures related to bathing but with normal motor development and mild, not deteriorated intellectual disability $[4,12]$. Mutation p.K306T is identified in patient with classical Dravet syndrome and in patient with myoclonic-astatic epilepsy $[11,12]$.

But this heterogenicity has not been described so far within the families. Johannesen et al. [12] described an 18-month-old infant with GEFS + whose father had febrile and afebrile seizures (EFS+). Lachance-Touchette et al. [10] reported on French Canadian families affected with IGE and related phenotypes; Cossette et al. [13] described a family with an autosomal dominant form of juvenile myoclonic epilepsy due to a mutation in GABRA1 gene; seizures types included: myoclonic seizures, generalized tonic clonic seizures and absences. All the known variants with this phenotype have been inherited from an equal or milder affected parent. The described patients were intellectually normal. EEG displayed generalized spike-wave discharges.

Kodera et al in 2016 [4] described one patient (mutation de novo c.859G $>$ T) with severe developmental delay whose interictal EEG findings did not fit any existing electroclinical syndromes. On the EEG (age 7 months) general slow background activity with multifocal spikes was present. At the age of 10 years suppression burst was observed. Clinical findings of this patient were very similar to the patient described by us. Felipe - Rucian reported on another case of neonatal encephalopathy due to the GABRA1 mutation with seizures and hypotonic tetraparesis [14].

Apart from epi seizures, and according to the data from http://www.lovd.nl/GABRA1.; the article is inaccessible; GABRAl variants have been described also in individuals with autism or intellectual disability without epilepsy.

The majority of the identified GABRA1 mutations are missense and arise de novo. Deletions of chromosomal loci carrying $\mathrm{GABA}_{\mathrm{A}}$ receptor subunit genes occur in conditions manifesting with seizures, like the Angelman syndrome. Shared features in patients with GABRA1 mutations include EEGs with generalized spike-wave discharges, half with photoparoxysmal response. Most common seizures types are tonic and myoclonic seizures [11]. Drugs increasing the synaptic GABA concentration like vigabatrin, valproate acid, gabapentin and lamotrigine have been shown to be effective in some patients with pathogenic $G A B R A 1$ variants $[4,11]$.

\section{CONCLUSIONS}

Our observation expands the spectrum of epilepsy syndromes associated with mutations that have been described so far.

Together with recent reports $[4,11,14]$ our data confirm that GABRA 1 mutation may be one of the underlying pathologies of infantile onset epileptic encephalopathy phenotypic spectrum of EIEE19.

Our case report confirms that mutation c799 C>A is a pathogenic variant and correct molecular diagnosis may significantly affect the diagnostics, clinical management and genetic counseling of children with EIEE and their families.

There is still much to be learned about specific aspects of the association between the mutation and the clinical features. Although current knowledge does not allow one to draw any definitive conclusions, it provides a solid basis for further research. The functional study on the mutated $\mathrm{GABA}_{\mathrm{A}}$ receptor has yet to be performed. The future studies may clarify the remaining uncertainties.

\section{Declaration of interests}

None of the authors have any conflicts of interest to disclose. We confirm that we have read the Journal's position on issues involved in ethical publication and affirm that this report is consistent with those guidelines.

\section{Authors' contributions}

Study concept and design: AO, ESZ

Participation in writing the manuscript AO, HM

Acquisition of data: AO, ESZ, HM

Genetic consultation: RŚ

Whole exome sequencing study and analysis: RP, MR, AW EEG analysis: IT

Neuropsychological assessment: JT

Critical revision of the manuscript for important intellectual content: ESZ, RP, HM, RŚ

\section{Acknowledgments and financial support}

We are grateful to the family involved in this study for participation. 


\section{REFERENCES}

[1] Khan S., Al Baradie R.: Epileptic encephalopathies: an overview. Epilepsy Res Treat. 2012: Article ID 403592.

[2] Kural Z., Ozer A.F.: Epileptic encephalopathies in adults and childhood. Epilepsy Res Treat 2012: Article ID 205131

[3] Holland K.D., Hallinan B.E.: What causes epileptic encephalopathy in infancy? : the answer may lie in our genes. Neurology 2010; 75: 1132-1133.

[4] Kodera H., Ohba Ch., Kato M., et al.: De novo GABRA1 mutations in Ohtahara and West syndromes. Epilepsia 2016; 57(4): 566-573.

[5] Helbig I., Tayoun A.A.: Understanding Genotypes and Phenotypes in Epileptic Encephalopathies. Mol Syndromol 2016; 7: 172-181.

[6] Galanopoulou A.S.: Mutations affecting GABAergic signaling in seizures. Pflugers Arch. 2010; 460(2): 505-523.

[7] Olsen R.W., Sieghart W.: International Union of Pharmacology. LXX. Subtypes of gamma-aminobutyric acid (A) receptors: classification on the basis of subunit composition, pharmacoly, and function. Update. Pharmacol Rev. 2008; 60(3): 243-260
[8] Glatt K., Glatt M., Lalande M.: Structure and organization of GABRB3 and GABRA5. Genomics 1997; 41: 63-69.

[9] Sigel E., Steinmann M.E.: Structure, Function, and Modulation of GABA Receptors. J Biol Chem. 2012; 287(48): 40224-40231.

[10] Lachance-Touchette P., Brown P., Meloche C., et al.: Novel alpha1 and gamma2 GABA receptor subunit mutations in families with idiopathic generalized epilepsy. Eur J Neurosci 2011; 34: 237-249.

[11] Johannesen K., Marini C., Pfeffer S., et al.: Phenotypic spectrum of GABRA1 from generalized epilepsies to severe epileptic encephalopathies. Neurology 2016, sep 13; 87 (11): 1140-1151.

[12] Carvill G. L., Weckhuysen S., McMahon J. M., et al.: GABRA1 and STXBP1: novel genetic causes of Dravet syndrome. Neurology 2014; 82: 1245-1253.

[13] Cossette P., Liu L., Brisebois K., et al.: Mutation of GABRA1 in an autosomal dominant form of juvenile myoclonic epilepsy. Nat Genet. 2002; 31: $184-189$.

[14] Felipe-Rucian A., Marce-Grau A., Raspall-Chaure M., et al.: GABRA1 neonatal encephalopathy: a clinical, genetic and pathological study. Eur J Paediatr Neurol 2015; 19S S1-S152. 